\title{
First association of Ceraeochrysa cincta (Schneider, 1851) (Neuroptera: Chrysopidae) with Maconellicoccus hirsutus (Green, 1908) (Hemiptera: Pseudococcidae) and evaluation of predation
}

\author{
Julia G. Alexandrino ${ }^{1 \oplus}$, Caleb C. Martins ${ }^{2 \pm=}{ }^{\oplus}$, Ana L. B. G. Peronti ${ }^{1 \oplus}$, Nilza M. Martinelli ${ }^{1 \oplus}$
}

${ }^{1}$ Universidade Estadual Paulista, Jaboticabal, SP, Brazil. ${ }^{2}$ Universidad Nacional Autónoma de Mexico, Mexico City, Mexico. 拝=-Corresponding author: calebcalifre@gmail.com

Edited by: Francisco J. S. Duque

Received: September 09, 2021. Accepted: December 27, 2021. Published: February 22, 2022.

\begin{abstract}
Maconellicoccus hirsutus (Green, 1908) (Hemiptera: Pseudococcidae) is a polyphagous pest introduced in Brazil in 2010. It has been successfully controlled in other countries by the employment of its natural enemies. Based in the economic importance of this pest plus the potential of chrysopids as its controlling agents, herein we report for the first time in Brazil the association of Ceraeochrysa cincta (Schneider, 1851) (Neuroptera: Chrysopidae) with this pseudococcid, evaluate the consumption of females of $M$. hirsutus by larvae of $C$. cincta, and the development of this predator when fed with that prey. Five hatched larvae of $C$. cincta from F2 generation were isolated in a Petri dish in controlled ambient, and fed with ten immature plus ten adult females of $M$. hirsutus offered and counted daily. The three instars of the predator were considered as distinct treatments. From five $C$. cincta larvae fed with $M$. hirsutus, only one had reached adulthood after 28 days. The mean duration of the $C$. cincta larval period was 20.73 days, with the $1^{\text {st }}, 2^{\text {nd }}$ and ${ }^{3 r d}$ instars being $6.40,5.33$ and 9.00 days respectively, but without significantly differences. A mean of 80 immatures and ca. 17 adults of $M$. hirsutus were predated by the $C$. cincta in its larval period, with the $3^{\text {rd }}$ instar being the phase of highest consumption of the prey. Based in our results, $M$. hirsutus is probably not a primary prey of $C$. cincta, but this chrysopid could be used as an alternative or complementary predator to control this pest.
\end{abstract}

Keywords: Biological control, green lacewing, natural enemy, pink hibiscus mealybug.

The pink hibiscus mealybug (PHM), Maconellicoccus hirsutus Green, 1908 (Hemiptera: Pseudococcidae), is an invasive pest, highly polyphagous, having achieved pest status on Hibiscus rosa-sinensis L. (Malvaceae), currently occurring in horticultural and agricultural crops and other woody ornamental plants throughout tropical and subtropical regions worldwide, with range expansion in the Americas and the Caribbean (Chong et al. 2015).

PHM was recorded for the first time in Brazil in late 2010 in the state of Roraima (Marsaro Júnior et al. 2013). After eight years this exotic species had been registered in other eight states, on 42 host species distributed in 20 families: Maranhão (Ramos et al. 2018), Pernambuco (Lopes et al. 2019; Sá \& Oliveira 2021); Alagoas (Broglio et al. 2015), Bahia (Lopes et al. 2019), Espírito Santo (Culik et al. 2013; Martins et al. 2019), Mato Grosso (Morais et al. 2015; Peres-Filho et al. 2017), São Paulo (Morais et al. 2015; Peronti et al. 2016) and Santa Catarina (Martins et al. 2019).

Maconellicoccus hirsutus has been successfully controlled, especially in Florida, California and Hawaii (USA), Mexico and in the Caribbean Islands (Chong et al. 2015) by the employment of biological control programs that includes mainly the predator Cryptolaemus montrouzieri Mulsant, 1850 (Coleoptera: Coccinellidae) and the parasitoids Anagyrus kamali Moursi, 1948 and Gyranusoidea indica Shafee et al., 1975 (Hymenoptera: Encyrtidae). However other 88 species of natural enemies, 42 parasitoids and 46 predators, have been associated with this mealybug around the word (García Morales et al. 2016), and some of them can be a significant effect on the reduction of this pest.

Among predators, 12 species are Neuroptera: nine Chrysopidae, one Coniopterygidae and two Hemerobiidae (Chong et al. 2015; Peronti et al. 2016). In Brazil, the only known record was of Ceraeochrysa sp. (Neuroptera: Chrysopidae) associated with pink hibiscus mealybug on
H. rosa-sinensis plants in the state of São Paulo (Peronti et al. 2016). Later, this specimen of lacewing was identified by third author (C. C. Martins) as Ceraeochrysa cincta (Schneider, 1851). This species has a wide distribution in the American continent, and has been associated with several agricultural pests, such as colonies of Leptococcus eugeniae (Miller \& Denno, 1977) (as Plotococcus eugeniae) (Hemiptera: Pseudococcidae) (Eisner \& Silberglied 1988; Freitas \& Penny 2001; Albuquerque 2009).

In Neotropics, including Brazil, several species of Ceraeochrysa Adams, 1982 are commonly found in diverse crops and are among the most promising pest control agents (Albuquerque et al. 2001; Freitas et al. 2009), their larvae usually feed on a variety of pests, such as aphids, thrips, whiteflies, mites and lepidopteran larvae (Freitas \& Penny 2001; Albuquerque et al. 2009; Freitas et al. 2009; Sosa \& Freitas 2010). According to Albuquerque et al. (2001), Ceraeochrysa species - including $C$. cincta - are considered as prime candidate for use in biological control programs.

Due the spreading of the pink hibiscus mealybug and the increasing of host plants in Brazil, studies on the predatory action of natural enemies already registered in the country are fundamental to support management programs of this pest. The present paper aims to report for the first time in Brazil the association of $C$. cincta with $M$. hirsutus, to evaluate the consumption of $M$. hirsutus nymphs and adult females by $C$. cincta larvae, and the development of this predator when fed with that prey.

For this purpose populations of $C$. cincta and $M$. hirsutus were rearing in BOD, with temperature $25 \pm 2^{\circ} \mathrm{C}$, relative humidity of 70 $\pm 10 \%$ and 12 hours of photophase at "Laboratório de Biossistemática de Hemiptera" (LABHEM), of the Plant Protection Department of the Faculdade de Ciências Agrárias e Veterinárias / UNESP, where the whole experiment was conducted. 
The green lacewings were reared according to the methodology described by Freitas (2001). The nymphs and adults of PHM, collected on $H$. rosa-sinensis plants, were transferred to fruits of organic Abelmoschus esculentus (L.) Moench (Malvaceae). When the okra fruits exhibited signs of wilt, after approximately two weeks of infestation, the insects were transferred to a new fruit.

The three instars of the predator $C$. cincta were considered as distinct treatments, created continuously and maintained throughout the all cycle in the same Petri dish. Each of them was considered a repetition, being five in total, for the two evaluations performed.

The newly hatched predator larvae obtained from the $\mathrm{F} 2$ generation were individualized in Petri dishes of $10 \mathrm{~cm}$ diameter, and for each one offered, simultaneously, ten specimens of immature and ten of adult females of $M$. hirsutus.

Evaluations of predatory mealybugs and the duration of each instar of the predator were carried out every 24 hours, counting the number of mealybugs predated and observing the presence of exuviae to confirm the larval instar of the Chrysopidae. The number of prey was sufficient for predator feeding and maintained by the replenishment of the PHM preyed.

From all of five replicates of $C$. cincta fed with $M$. hirsutus, only one had reached adulthood after 28 days. Two died in the pupa phase, and two died at the end of the third instar (Tab. 1).

The mean duration of the three larval instars of $C$. cincta was 20.73 days, being the $1^{\text {st }}, 2^{\text {nd }}$ and $3^{\text {rd }}$ of $6.40,5.33$ and 9.00 days respectively. The duration of the first and second instars was shorter than the duration of third instar, not differentiating between them. De Bortoli et al. (2009) evaluation of the biological aspects of $C$. cincta fed with larvae and eggs of Sitotroga cerealella Olivier, 1789 (Lepidoptera: Gelechiidae), Diatraea saccharalis (Fabricius, 1794) and Ephestia kuehniella (Zeller, 1879) (= Anagasta kuehniella) (both Lepidoptera: Pyralidae), and found that the larval period of this predator lasted $12.92,13.25$ and 14.79 respectively, when fed with these preys. One of the likely reasons for the difference of the larval period duration of $C$. cincta in the present study and that of De Bortoli et al. (2009) is the difference of preys utilized, herein we used the Hemipteran M. hirsutus, whereas De Bortoli et al. (2009) used three species of Lepidoptera. Another possible explanation to this difference is the number of repetitions used in the studies, which are greater in De Bortoli et al. (2009).

However, De Bortoli et al. (2005) studying the nutritional aspects of $C$. cincta fed with different coccoids species, including Selenaspidus spp. (Hemiptera: Diaspididae), Coccus sp. (Hemiptera: Coccidae) and Praelongorthezia sp. (= Orthezia sp.) (Hemiptera: Ortheziidae), verified that when fed on later prey, the second instar larvae of the green lacewing died after one to three days, probably due to the wax that recovers the body of these mealybugs, which could obstruct the predator's mouth tube composed by the juxtaposition of maxilla and mandible. This may be a possible explanation for the non-finalization of the cycle of most $C$. cincta replicates fed with $M$. hirsutus, because it was possible to observe in the individuals of third instar a large amount of wax involving their mouth parts, which made its feeding difficult and reflected in poor development of this predator.

Another possible explanation to the high mortality of $C$. cincta fed with $M$. hirsutus is the inadequacy of the prey regarding the necessary nutrients to the development of this predator. Despite the chemical composition of the prey of Chrysopidae is similar in terms of nutrients, its concentrations and accessibility to the predator vary from species to species (Yazlovetsky 1992; Cohen 1998; Albuquerque 2009), which influences the development of these organisms and can be noted by the different performances exhibited by the same species when fed with different preys (Thompson \& Hagen 1999; Albuquerque 2009).

The difference in consumption between immature and adult of $M$. hirsutus throughout the larval phase of $C$. cincta was significant. During the whole larval cycle of the green lacewing, an average of 80 immature coccoids was consumed, where only 17.07 adults were predated. The third instar of $C$. cincta was the phase of higher consumption of individuals (53.00), when compared to 20.40 and 23.67 of the first and second instars, respectively.

It was also the instar where it had a significant increase in the consumption of immature individuals, but adult consumption, despite being larger when compared with previous instars, did not differ from them. Gonçalves-Gervásio \& Santa-Cecília (2001), studied the food consumption of the different stages of development of Dysmicoccus brevipes Cockerell, 1893 (Hemiptera: Pseudococcidae) by Chysoperla externa (Hagen, 1861) (Neuroptera: Chrysopidae) and found a relatively higher nymphs consumption than those observed in the present study, being 135.8 individuals. However, the number of adults of $D$. brevipes, counted by these authors, was lower, 10 adults throughout the larval stage of the predator. The developmental period of the larval phase of $C$. cincta fed with $M$. hirsutus was longer when compared to other foods and in the present study most individuals failed to complete their cycle of life when fed just with this pseudococcid, surviving only up to the third instar, however a larger number of replicates may demonstrate different results.

This was the first report of $C$. cincta associated with $M$. hirsutus. Although this pseudococcid is not a primary prey of $C$. cincta this green lacewing could be used as an alternative or complementary predator, along with other natural enemies such as parasitoids and other predators.

In addition to the present study, other prey, mainly species that normally infest plants of Hibiscus spp. and other Malvacea species could be testing as diet to $C$. cincta. Through the results of this study and confirmation of these interactions, plus information of other natural enemies associated with the pink hibiscus mealybug, management strategies can be suggested in the future.

Table 1. Duration of instar of Ceraeochrysa cincta and number (average) of Maconellicoccus hirsutus predated.

\begin{tabular}{ccccc}
\hline \multicolumn{2}{c}{ Ceraeochrysa cincta } & \multicolumn{3}{c}{ Number of mealybugs preyed } \\
\hline Phase of development & Duration of instars (days) & Nymphs & Adults & Total \\
\hline $1^{\text {st instar }}$ & $6.40 \mathrm{ab}$ & $19.00 \mathrm{Ab}$ & $1.40 \mathrm{Ba}$ & 20.40 \\
$2^{2 \mathrm{in}}$ instar & $5.33 \mathrm{~b}$ & $20.67 \mathrm{Ab}$ & $3.00 \mathrm{Ba}$ & 23.67 \\
$3^{\text {st }}$ instar & $9.00 \mathrm{a}$ & $40.33 \mathrm{Aa}$ & $12.67 \mathrm{Ba}$ & 53.00 \\
\hline Total & 20.73 & 80.00 & 17.07 & 97.07 \\
\hline
\end{tabular}

${ }^{*}$ Averages followed by the same capital letter on the same line do not differentiate between them; averages followed by the same lowercase letter from the same column do not differentiate between them.

\section{Acknowledgments}

We are grateful to Faculdade de Ciências Agrárias e Veterinárias / UNESP for general support. We are also thankful to two anonymous reviewers by the suggestion on original manuscript. CCM acknowledges Programa de Becas Posdoctorales DGAPA-UNAM (2019-2021) for a postdoctoral fellowship.

\section{Author's Contributions}

JGA reared the populations of $C$. cincta and $M$. hirsutus, carried out the evaluation of amount of preyed mealybugs and the duration of each instar of the Chrysopidae, analyzed the data, and wrote the manuscript. CCM performed species identification, reviewed the literature and wrote the manuscript. ALP and NMM supervised the study, reviewed the literature and wrote the manuscript. 


\section{Conflict of Interest Statement}

No potential conflict of interest was reported by the authors.

\section{References}

Albuquerque, G. S. (2009) Crisopídeos (Neuroptera: Chrysopidae). In: Panizzi, A. R.; Parra, J. R. P. (Eds.), Bioecologia e nutrição de insetos: base para o manejo integrado de pragas, pp. 969-1022. Brasília: Embrapa Informação Tecnológica.

Albuquerque, G. S.; Tauber, C. A.; Tauber, M. J. (2001) Chrysoperla externa and Ceraeochrysa spp.: potential for biological control in the New World tropics and subtropics. In: McEwen, P.; New, T. R.; Whittington, A. E. (Eds.), Lacewings in the crop environment, pp. 408-423. Cambridge: Cambridge University.

Broglio, S. M. F; Cordero, E. P.; Santos, J. M. dos; Micheletti, L. B. (2015) Registro da cochonilha-rosada-do-hibisco infestando frutiferas em Maceió, Alagoas, Brasil. Revista Caatinga, 28: 242-248.

Chong, J. H.; Aristizábal, L. F.; Arthurs, S. P. (2015) Biology and management of Maconellicoccus hirsutus (Hemiptera: Pseudococcidae) on ornamental plants. Journal of Integrated Pest Management, 6: 1-14. doi: 10.1093/jipm/pmv004

Cohen, A. C.; Smith, L. K. A (1998) New concept in artificial diets for Chrysoperla rufilabris: the efficacy of solid diets. Biological Control, 13: 49-54. doi: 10.1006/bcon.1998.0636

Culik, M. P.; Fornazier, M. J.; Santos Martins, D.; Peronti, A. L. B. G; Zanuncio, J. C. (2013) The invasive mealybug Maconellicoccus hirsutus: lessons for its current range expansion in South America and invasive pest management in general. Journal of Pest of Science, 86: 387-398. doi: 10.1007/s10340-013-0512-z

De Bortoli, A. S.; Takao, M. A.; Silva, N. R.; Brito, H. C. (2005) Aspectos nutricionais de Ceraeochrysa cincta Schneider, 1851 (Neuroptera: Chrysopidae) em diferentes presas. Revista de Agricultura, 80: 1-11. doi: 10.37856/bja.v80i1.1411

De Bortoli, S. A.; Murata, A. T.; Brito, C. H.; Narciso, R. S. (2009) Aspectos biológicos de Ceraeochrysa cincta (Neuroptera: Chrysopidae), em condições de laboratório. Revista de Biologia e Ciências da Terra, 9: 101-106.

Eisner, T.; Silberglied, R. E. (1988) A chrysopid larva that cloaks itself in mealybug wax. Psyche, 95: 15-19. doi: 10.1155/1988/97301

Freitas, S. de (2001) O uso de crisópideos no controle biológico de pragas. Jaboticabal: Funep.

Freitas, S. de; Penny, N. D. (2001) The green lacewings (Neuroptera: Chrysopidae) of Brazilian agro-ecosystems. Proceedings of the California Academy of Sciences, 52: 245-395.

Freitas, S. de; Penny, N. D.; Adams, P. A. (2009) A revision of the New World genus Ceraeochrysa (Neuroptera: Chrysopidae). Proceedings of the California Academy of Sciences, 60(4): 503-610.

García Morales, M.; Denno, B. D.; Miller, D. R.; Miller, G. L.; Ben-Dov, Y.; Hardy, N. B. (2016) ScaleNet: A literature-based model of scale insect biology and systematics. Database. doi: 10.1093/database/ bav118

Gonçalves-Gervásio, de R. C. R.; Santa-Cecília, L. V. C. (2001) Consumo alimentar de Chrysoperla externa sobre as diferentes fases de desenvolvimento de Dysmicoccus brevipes, em laboratório. Pesquisa Agropecuaria Brasileira, 36: 387-391. doi: 10.1590/ S0100-204X2001000200024

Lopes, F. S. C.; Oliveira, J. V.; Oliveira, J. E. M.; Oliveira, M. D.; Souza, A. M. (2019) Plantas hospedeiras de cochonilhas-farinhentas (Hemiptera: Pseudococcidade) em cultivos de videira. Pesquisa Agropecuária Tropical, 49: e54421. doi: 10.1590/1983-40632019v4954421

Marsaro Júnior, A. L.; Peronti, A. L. B. G.; Penteado-Dias, A. M.; Morais, E. G. F.; Pereira, P. R. V. S. (2013) First report of Maconellicoccus hirsutus (Green, 1908) (Hemiptera: Coccoidea: Pseudococcidae) and the associated parasitoid Anagyrus kamali Moursi, 1948 (Hymenoptera: Encyrtidae), in Brazil. Brazilian Journal of Biology, 73: 413-418. doi: 10.1590/S1519-69842013000200024

Martins, D. S.; Fornazier, M. J.; Peronti, A. L. B. G.; Culik, M. P.; Souza, C. A. S.; Taques, R. C.; Zanuncio Junior, J. S.; Queiroz, R. B.
(2019) Maconellicoccus hirsutus (Hemiptera: Pseudococcidae) in Brazil: recent spread, natural enemies, and new hosts. Florida Entomologist, 102(2): 438-443. doi: 10.1653/024.102.0225

Morais, E. G. F.; Peronti, A. L. B. G.; Marsaro Júnior, A. L.; Amaro, G. C. (2015) Cochonilha rosada, Maconellicoccus hirsutus (Green). In: Vilela, E. F.; Zucchi, R. A. (Eds.), Pragas introduzidas no Brasil: insetos e ácaros, pp. 328-344. Piracicaba: FEALQ.

Peres-Filho, O.; Ben-Dov, Y.; Wolff, V. R. S.; Dorval, A.; Souza, M. D. (2017) Maconellicoccus hirsutus (Green) register in teak forest stands in the Mato Grosso State, Brazil. Floresta e Ambiente, 24: e20150157. doi: 10.1590/2179-8087.015715

Peronti, A. L. B. G.; Martinelli, N. M.; Alexandrino, J. G.; Marsaro Júnior, A. L.; Penteado-Dias, A. M.; Almeida, L. M. (2016) Natural enemies associated with Maconellicoccus hirsutus (Hemiptera: Pseudococcidae) in the state of São Paulo, Brazil. Florida Entomologist, 99: 21-25. doi: 10.1653/024.099.0105

Ramos, A. S. J. C.; Peronti, A. L. B. G.; Kondo, T.; Lemos, R. N. S. (2018) First record of Crypticerya zeteki (Cockerell, 1914) (Monophlebidae) in Brazil and Maconellicoccus hirsutus (Green, 1908) (Pseudococcidae) in the state of Maranhão. Brazilian Journal of Biology, 78: 87-90. doi: 10.1590/1519-6984.05416

Sá, M. G. R. de; Oliveira, J. E. M. (2021) Mealybugs on fruit crops in the São Francisco Valley, Brazil. African Journal of Agricultural Research, 16(6): 822-828. doi: 10.5897/AJAR2020.15363

Sosa, F.; Freitas, S. de (2010) New Neotropical species of Ceraeochrysa Adams (Neuroptera: Chrysopidae). Zootaxa, 2562: 57-65. doi: 10.11646/zootaxa.2562.1.4

Thompson, S. N.; Hagen, K. S. (1999) Nutrition of entomophagous insects and other arthropods. In: Bellows, T. S.; Fisher, T. W. (Eds.), Handbook of biological control: principles and applications of biological control, pp. 594-652. San Diego: Academic.

Yazlovetsky, I. G. (1992) Development of artificial diets for entomophagous insects by understanding their nutrition and digestion. In: Anderson, T. E.; Leppla, N. C. (Eds.), Advances in insect rearing for research and pest management, pp. 41-62. Boulder: Westview. 